
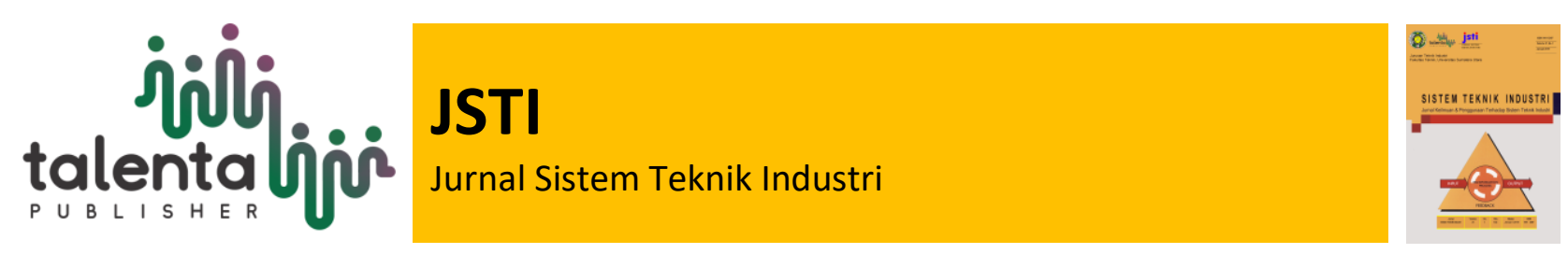

\title{
Implementasi Early Warning System Berbasis Risiko dalam Pemantauan Laba sebagai Upaya Pengelolaan Risiko di PT XYZ
}

\author{
Fatma Rizki Hardiana ${ }^{1}$, Irwan Iftadi ${ }^{2}$ \\ ${ }^{1,2}$ Fakultas Teknik, Universitas Sebelas Maret Surakarta
}

\begin{abstract}
PT XYZ as a company that has a net profit that deviates from the specified target and context, for this reason it is necessary to develop a risk-based early warning system that is made as an action in risk management. For leading indicators, after data collection and indicators will be analyzed, then data processing is performed, namely normality test, analytical analysis, multiple linear regression analysis approved has fulfilled F test, T test, and assumption test. For lagging indicators, data processing is carried out by categorizing earnings which are divided into three categories namely safe, alert and hazardous. Based on PT XYZ's financial data for 2006-2017, the leading indicator obtained a profit model = $1119035,722+0.120 \mathrm{HPP}+0.836$ operating costs, for dependent variables such as earnings and independent variables namely HPP and operating expenses. For lagging the indicator used three profit categories namely danger, alert and safe. Within the categorization limit, it is necessary to do data every year because the data available for now is only based on 20062017 earnings data. An early warning system is issued using data 2 months before that can be detected. Keyword: Profit, Early Warning System, Risk Management
\end{abstract}

\begin{abstract}
Abstrak PT XYZ memiliki risiko laba bersih yang tidak sesuai dengan target. Penelitian dilakukan bertujuan untuk mengembangkan early warning system berbasis risiko sebagai tindakan dalam manajemen risiko. Penelitian dilakukan dengan dua tahapan, yaitu menentukan indikator laba dan membuat early warning system. Dalam menentukan indikator, hal yang dilakukan adalah menguji indikator tersebut. Terdapat dua indikator dalam manajemen risiko, yaitu leading dan lagging indikator. Untuk leading indikator, proses yang dilakukan adalah pengumpulan data dan dilanjutkan mengolah data yaitu uji normalitas, analisis korelasi, dan analisis regresi linier. Untuk lagging indikator, dilakukan pengolahan data dengan melakukan pengkategorian laba yang dibagi menjadi tiga kategori yaitu aman, waspada dan bahaya. Berdasarkan data keuangan PT XYZ tahun 2006-2017, untuk leading indikator diperoleh hasil yang mempengaruhi laba yaitu HPP dan beban usaha. Dalam pembuatan dashboard early warning system diperlukan informasi mengenai latar belakang, dampak dari risiko yang ada, indikator yang mempengaruhi, serta informasi posisi laba menggunakan grafik maupun gauge. Early warning system dikeluarkan menggunakan data dua bulan sebelumya agar dapat dilakukan pendeteksian.
\end{abstract}

Kata Kunci: Laba, Early Warning System, Manajemen Risiko

Received 6 April 2020 | Revised 27 April 2020 | Accepted 22 Mei 2020

*Corresponding author at: JI. Ir. Sutami No. 36 A, Pucangsawit, Jebres, Surakarta 57126

E-mail address: fatmarizkihardiana@student.uns.ac.id, iftadi@gmail.com

Copyright (C) 2020 Published by Talenta Publisher, ISSN: 1411-5247 e-ISSN: 2527-9408

Journal Homepage: http://talenta.usu.ac.id/jsti 


\section{Latar Belakang}

Berdasarkan Undang-Undang Republik Indonesia No.19 Tahun 2003, perusahaan memiliki tujuan dalam penyediaan barang atau jasa yang memiliki mutu tinggi dan mengejar keuntungan yang disesuaikan dengan prinsip pengelolaan perusahaan yang sehat. PT XYZ sebagai salah satu perusahaan di Indonesia tentu selalu berusaha untuk memberikan manfaat yang besar, namun dalam praktiknya tentu terdapat unsur ketidakpastian yang berasal dari lingkungan eksternal maupun internal sehingga dapat memberi dampak terhadap pencapaian tujuan perusahaan. Ketidakpastian merupakan sesuatu yang tidak dapat diperkirakan sebelumnya, mendefinisikan risiko sebagai peluang terjadinya hasil yang tidak diinginkan sehingga risiko hanya terkait dengan situasi yang memungkinkan munculnya hasil negatif serta berkaitan dengan kemampuan memperkirakan terjadinya hasil negatif tadi [1].

PT XYZ menerapkan manajemen risiko menggunakan framework SNI ISO 31000:2011 (selanjutnya disebut ISO 31000). Menurut ISO 31000 pengertian risiko sendiri merupakan dampak dari ketidakpastian pada sasaran. Sedangkan, sasaran adalah target/tujuan/segala sesuatu yang ingin dicapai perusahaan dengan kaidah-kaidah spesifik, dapat diukur, disepakati, realistis dan ada batas waktu [2]. Dalam usaha menjaga kelangsungan perusahaan agar dapat berkembang dalam jangka yang panjang, sebuah perusahaan harus memiliki kemampuan untuk memperoleh suatu laba, yang berarti memiliki kemampuan untuk melakukan penjualan suatu produk, pengendalian biaya, pemanfaatan sumber keuangan, sumber fisik, sumber daya manusia serta terus melakukan inovasi produk. Besarnya laba yang diperoleh suatu perusahaan, mampu menjadi sebuah tolak ukur berhasil tidaknya manajemen tersebut dalam mengelola perusahaannya.

Penjualan serta biaya memiliki pengaruh terhadap laba atau keuntungan bersih. Penjualan yang meningkat serta biaya yang efisien tentunya berpengaruh untuk membuat laba bersih yang diperoleh suatu perusahaan meningkat. Terdapat hubungan yang erat mengenai volume penjualan terhadap peningkatan laba bersih perusahaan, dalam hal ini dapat dilihat dari laporan laba-rugi perusahaan [3]. Dalam penjelasan tersebut disimpulkan bahwa laba akan diperoleh apabila penjualan produk lebih besar daripada biaya-biaya yang dikeluarkan. Perolehan laba bersih juga dapat dipengaruhi oleh biaya yang digunakan untuk melakukan kegiatan perusahaan. Apabila perusahaan dapat menekan biaya operasional, maka perusahaan akan dapat meningkatkan laba bersih, demikian juga sebaliknya [4]. Kuswadi dalam Efilia (2014) menyatakan dalam perhitungan laba rugi, besarnya biaya beban usaha ini akan mengurangi laba atau menambah rugi perusahaan. Selain itu, menurut Juki dalam Efilia (2014) juga menyatakan, tingginya biaya operasi akan membuat laba turun, begitu juga jika biaya operasi rendah maka laba akan meningkat [5].

Sebagai sebuah perusahaan, PT XYZ tentunya memiliki salah satu risiko yaitu mengenai laba bersih perusahaan yang fluktuatif dan mampu melenceng dari sasaran dan konteks yang telah ditetapkan PT XYZ sendiri. Menurut Novita (2018), laba bersih yang tinggi atau semakin meningkat menunjukkan bahwa kinerja perusahaan semakin baik, yang artinya kegiatan operasi perusahaan semakin efisien. Hal ini memberikan keuntungan karena perusahaan dapat 
memperluas usahanya dan prestasi perusahaan dimasa yang akan datang dapat meningkat pula. Laba yang rendah atau semakin menurun menunjukkan bahwa kinerja perusahaan yang kurang baik dan kegiatan operasi perusahaan semakin kurang efisien. Hal ini akan merugikan perusahaan karena akan sulit memperluas usahanya dan prestasi perusahaan juga dapat menurun dimasa yang akan datang. Oleh karena itu perlu untuk diketahui faktor-faktor penyebab berfluktuasinya laba bersih agar perusahaan dapat mencari solusi atau alternatif pemecahan masalah sebagai bentuk evaluasi kinerja perusahaan [6]. Adanya risiko tersebut tentu mendorong perusahaan untuk mencoba mengembangkan early warning system yang berbasis risiko yang bertujuan sebagai tindakan preventif dalam hal mendeteksi risiko yang terjadi. Early warning system berbasis risiko merupakan sebuah sistem yang dibuat untuk memberikan sinyal/peringatan/tanda awal kepada risk owner dalam bentuk perkiraan besar risiko yang dapat berpotensi pada periode tertentu, penyebab terjadinya risiko, serta memberikan rekomendasi dalam rangka pengendalian risiko yang dimaksud [7].

Untuk penerapan early warning system dibutuhkan indikator, untuk manajemen risiko sendiri terdapat dua indikator, yaitu lagging indikator dan leading indikator. Lagging indikator merupakan indikator dari suatu kejadian atau peristiwa yang telah terjadi bersamaan dengan dampak dari kejadian itu sendiri. Dalam penelitian ini maka lagging indikator yang digunakan adalah laba itu sendiri. Sedangkan leading indikator merupakan indikator dari suatu kegiatan yang berupa sebuah proses dan dilakukan untuk memprediksi kejadian dimasa depan serta dapat mengubah kejadian tersebut [8]. Dalam penelitian ini penjualan, beban usaha dan harga pokok penjualan digunakan sebagai leading indikator.

\section{Metode Penelitian}

Berikut langkah-langkah yang dilakukan dalam penelitian tersebut dapat dilihat dalam gambar dibawah ini.

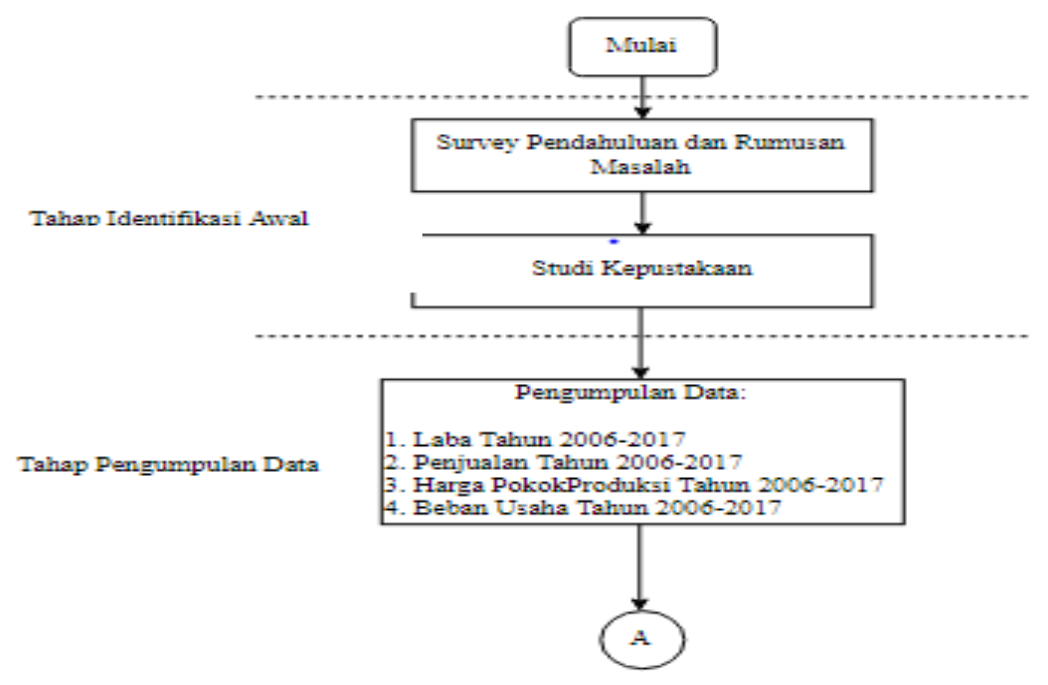

Gambar 1 .Flowchart Metodologi Penelitian 


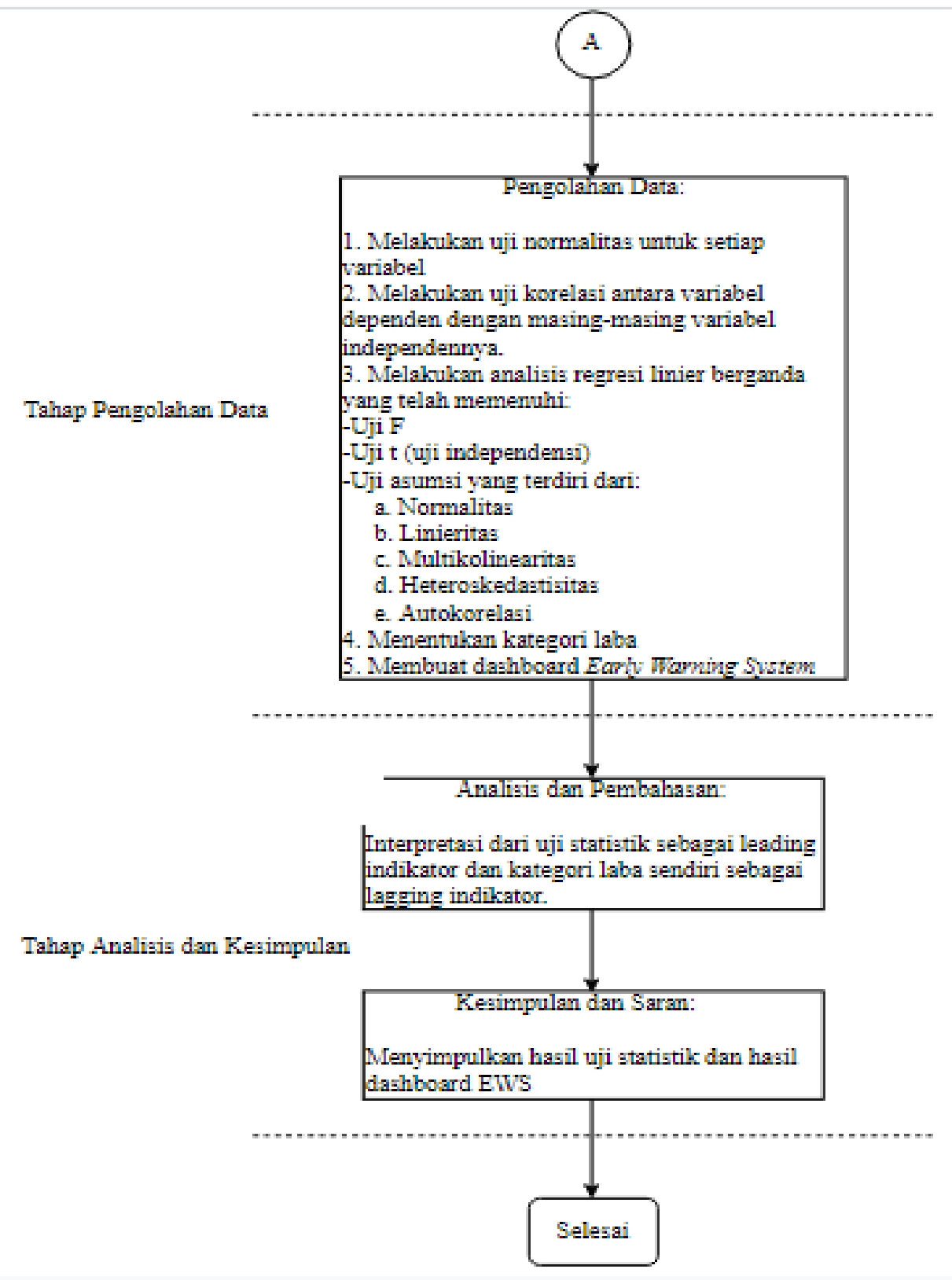

Gambar 1 Flowchart Metodologi Penelitian

\section{Hasil dan Pembahasan}

\subsection{Leading Indikator}

\subsubsection{Analisis Korelasi}

Analisis korelasi digunakan untuk mengetahui adanya korelasi antara indikator penjualan, harga pokok penjualan dan beban usaha terhadap laba di PT XYZ berdasarkan laporan tahunan bagian laporan keuangan tahun 2006-2017. Salah satu asumsi analisis korelasi adalah data berdistribusi normal. Hasil uji normalitas menggunakan IBM SPSS 20 dapat dilihat pada tabel berikut. 


\begin{tabular}{|l|c|c|c|c|c|c|}
\hline \multicolumn{7}{|c|}{ Tests of Normality } \\
\hline & \multicolumn{2}{|c|}{ Kolmogorov-Smirnov } & \multicolumn{3}{|c|}{ Shapiro-Wilk } \\
\cline { 2 - 8 } & Statistic & df & Sig. & Statistic & df & Sig. \\
\hline Laba & 0.144754 & 12 & $.200^{*}$ & 0.95494 & 12 & 0.71 \\
\hline Penjualan & 0.162256 & 12 & $.200^{*}$ & 0.92676 & 12 & 0.347 \\
\hline HPP & 0.139069 & 12 & $.200^{*}$ & 0.92846 & 12 & 0.364 \\
\hline Beban_Usaha & 0.148505 & 12 & $.200^{*}$ & 0.90801 & 12 & 0.201 \\
\hline
\end{tabular}

Gambar 2 Hasil SPSS Uji Normalitas Shapiro Wilk

Berdasarkan output nilai sig. Shapiro Wilk, apabila nilai tersebut $>\alpha$ (nilai sig. $>0,05$ ) berarti data berdistribusi normal. Dari hasil tabel diatas maka dapat disimpulkan seluruh variabel berdistribusi normal.

Setelah data diketahui berdistribusi normal, maka analisis korelasi dapat dilakukan menggunakan IBM SPSS 20 yang diperoleh hasil seperti tabel berikut.

\begin{tabular}{|l|l|c|c|c|c|}
\hline \multicolumn{6}{|c|}{ Correlations } \\
\hline \multirow{2}{*}{} & Laba & Penjualan & HPP & Beban_Usaha \\
\hline \multirow{3}{*}{ Laba } & $\begin{array}{l}\text { Pearson } \\
\text { Correlation }\end{array}$ & 1 & $.882^{* *}$ & $.816^{* *}$ & $.787^{* *}$ \\
\cline { 2 - 6 } & Sig. (2-tailed) & & 0.000148 & 0.00121 & 0.00236129 \\
\cline { 2 - 6 } & N & 12 & 12 & 12 & 12 \\
\hline
\end{tabular}

Gambar 3 Hasil SPSS Output Uji Korelasi

Berdasarkan output SPSS Tabel 4.2, apabila dianalisis menggunakan kriteria $r_{\text {tabel }}$ diketahui bahwa $\mathrm{df}=\alpha ; \mathrm{n}-2$, atau $\mathrm{r} 10 ; 5 \%$ maka diperoleh nilai $\mathrm{r}_{\text {tabel }}$ sebesar 0,576. Dengan membandingkan nilai $r_{\text {hitung }}$ dengan $r_{\text {tabel }}$, maka dapat disimpulkan bahwa:

1. Laba mempunyai korelasi kuat dengan penjualan, karena koefisien korelasi laba dengan penjualan lebih besar dari $r_{\text {tabel }}(0,882>0,576)$.

2. Laba mempunyai korelasi kuat dengan HPP, karena koefisien korelasi laba dengan HPP lebih besar dari $\mathrm{r}_{\text {tabel }}(0,816>0,576)$.

3. Laba mempunyai korelasi kuat dengan beban usaha, karena koefisien korelasi laba dengan beban usaha lebih besar dari $\mathrm{r}_{\text {tabel }}(0,787>0,576)$.

\subsubsection{Uji Asumsi Klasik}

Terdapat empat uji asumsi klasik, yaitu: Uji Normalitas, Uji Multikolinearitas, Uji Heteroskedastisitas, dan Uji Autokorelasi. Untuk mengetahui apakah sebaran residual mengikuti distribusi normal akan diuji melalui SPSS. Model regresi yang baik adalah model regresi yang berdistribusi normal atau mendekati normal [9]. Berdasarkan output nilai sig. Shapiro-Wilk $>\alpha$ $(0,389>0,05)$. Karena nilai tersebut masih lebih besar dari tingkat kekeliruan 5\% sehingga dapat disimpulkan bahwa data residual berdistribusi normal. Selanjutnya untuk mengetahui apakah 
terdapat korelasi atau hubungan yang kuat antara dua variabel bebas atau lebih dalam sebuah model regresi berganda maka dilakukan uji multikolinearitas. Model regresi yang baik seharusnya tidak terjadi korelasi antara variabel bebasnya. Jika variabel bebas saling berkorelasi, maka variabel ini tidak ortogonal. Variabel ortogonal adalah variabel bebas yang nilai korelasi antar sesama variabel bebas sama dengan nol. Berdasarkan hasil SPSS diperoleh nilai toleransi untuk masing-masing variabel :

1. Nilai toleransi Penjualan, $0,00445326<0,10$

2. Nilai toleransi HPP, $0,00539067<0,10$

3. Nilai toleransi Beban Usaha, 0,15298326>0,10

Maka dapat disimpulkan terjadi multikolinieritas antara variabel bebas Penjualan dan HPP karena memiliki nilai toleransi kurang dari 0,1. Selanjutnya, berdasarkan tabel diatas diperoleh VIF untuk masing-masing variabel :

1. VIF variabel Penjualan, $224,5547>10$

2. VIF variabel HPP, $185,5057>10$

3. VIF variabel Beban Usaha, $6,536663<10$

Maka dapat disimpulkan terjadi multikolinieritas antar variabel bebas Penjualan dan HPP. Ketika menghadapi persoalan tentang multikolinearitas, salah satu metode sederhana yang bisa dilakukakan adalah dengan menghilangkan salah satu variabel independen yang mempunyai hubungan linier kuat [10]. Dari tabel dapat diketahui variabel Penjualan memiliki nilai VIF terbesar, sehingga variabel tersebut menjadi variabel yang dipilih untuk dihilangkan. Sebelum dilakukan uji multikolinearitas untuk variabel HPP dan beban usaha, perlu dilakukan uji normalitas terdahulu untuk menunjukkan bahwa residual tersebut tetap berdistribusi normal. Setelah diketahui data berdistribusi normal selanjutnya dapat dilakukan uji multikolinearitas kembali menggunakan IBM SPSS 20 yang diperoleh hasil sebagai berikut.

1. Nilai toleransi HPP, $0,6821784>0,10$

2. Nilai toleransi Beban Usaha, 0,6821784>0,10
VIF variabel HPP, $1,4658923<10$

VIF Beban Usaha, $1,4658923<10$

Maka dapat disimpulkan tidak terjadi multikolinieritas antar variabel bebas HPP dan Beban Usaha, artinya bahwa diantara variabel bebas HPP dan Beban Usaha tidak terdapat korelasi yang cukup kuat antara sesama variabel bebas dan data layak digunakan untuk analisis regresi berganda. 
Selanjutnya dilakukan uji heteroskedastisitas yang merupakan indikasi varian antara residual tidak homogen yang mengakibatkan nilai taksiran yang diperoleh tidak lagi efisien. Model regresi yang baik seharusnya tidak terjadi heteroskedastisitas atau dikatakan homokedastisitas. Dengan menggunakan IBM SPSS 20 diperoleh hasil nilai signifikansi untuk variabel HPP adalah 0,06 dan variabel biaya usaha adalah 0,404 . Karena nilai signifikansi diatas $>0,05$ maka dapat disimpulkan bahwa tidak terjadi heteroskedastisitas atau asumsi homoskedastisitas terpenuhi.

Terakhir uji autokorelasi dilakukan untuk mengetahui apakah terdapat hubungan antara suatu periode $t$ dengan periode $t$ sebelumnya. Uji ini dapat dilakukan dengan uji run test melalui IBM SPSS 20 yang diperoleh hasil nilai signifikansi adalah 1 yang berarti $>0,05$. Maka dapat disimpulkan bahwa tidak terdapat masalah gejala autokorelasi.

\subsubsection{Uji Hipotesis}

\section{Uji Hipotesis Parsial (Uji t)}

Berdasarkan hasil pengolahan diperoleh nilai $\mathrm{t}_{\text {hitung }}$ untuk variabel HPP adalah 3,21 dengan nilai signifikansi 0,0107. Karena $t_{\text {hitung }}>t_{\text {tabel }}(3,21>2,228)$ maka pada tingkat kekeliruan 5\% Ho ditolak sehingga $\mathrm{H} 1$ diterima. Artinya pada tingkat kepercayaan 95\% dapat disimpulkan bahwa HPP memiliki pengaruh signifikan terhadap laba bersih.

Selanjutnya berdasarkan hasil pengolahan diperoleh nilai thitung untuk variabel beban usaha adalah 2,827 dengan nilai signifikansi 0,0198. Karena $t_{\text {hitung }}>t_{\text {tabel }}(2,827>2,228)$ maka pada tingkat kekeliruan 5\% Ho ditolak sehingga $\mathrm{H} 1$ diterima. Artinya pada tingkat kepercayaan $95 \%$ dapat disimpulkan bahwa beban usaha memiliki pengaruh signifikan terhadap laba bersih.

\section{Uji Hipotesis Simultan (Uji F)}

Uji $F$ dilakukan untuk mengetahui pengaruh secara simultan variabel independen terhadap variabel dependen. Pengujian ini bertujuan untuk membuktikan apakah HPP dan beban usaha secara simultan berpengaruh signifikan terhadap laba bersih, berdasarkan hasil pengolahan diperoleh nilai Fhitung sebesar 20,909 dengan nilai signifikansi 0,000 karena Fhitung > Ftabel $(20,909>4,10)$ maka pada tingkat kekeliruan 5\% H0 ditolak sehingga H1 diterima. Artinya dengan tingkat kepercayaan 95\% HPP dan beban usaha secara simultan memiliki pengaruh signifikan terhadap laba bersih

\subsubsection{Koefisien Determinasi}

Koefisien determinasi digunakan untuk menghitung besarnya peranan atau pengaruh dari variabel bebas atau independen terhadap variabel dependen. Koefisien determinasi ini akan menunjukkan berapa persentase yang mempengaruhi laba sebagai variabel dependen yang diakibatkan oleh HPP dan beban usaha sebagai variabel independen. 


\begin{tabular}{|c|c|c|c|c|}
\hline \multicolumn{5}{|c|}{ Model Sum mary } \\
\hline Model & $R$ & R Square & $\begin{array}{c}\text { Adjusted R } \\
\text { Square }\end{array}$ & $\begin{array}{c}\text { Std. Error of } \\
\text { the Estimate }\end{array}$ \\
\hline 1 & $.907^{\mathrm{a}}$ & 0.823 & 0.784 & 327641.554 \\
\hline
\end{tabular}

a. Predictors: (Constant), HPP, Beban_Usaha

Gambar 4 Hasil SPSS Output Analisis Regresi Linier Berganda

Berdasarkan perhitungan menggunakan program IBM SPSS Statistics 20 pada tabel dapat dilihat nilai R Square sebesar 0,823. Nilai tersebut digunakan untuk melihat besarnya pengaruh HPP dan beban usaha terhadap laba dengan cara menghitung Koefisien Determinasi (KD) menggunakan rumus sebagai berikut:

$\mathrm{KD}=\mathrm{r}^{2} \times 100 \%$

$\mathrm{KD}=0,823 \times 100 \%$

$\mathrm{KD}=82,3 \%$

Hasil dari perhitungan tersebut menunjukan bahwa HPP dan beban usaha mampu memengaruhi perubahan yang terjadi pada laba sebesar $82,3 \%$. Sedangkan sisanya yaitu sebesar $17,7 \%$ dipengaruhi oleh variabel lain diluar variabel HPP dan beban usaha.

\subsubsection{Sumbangan Efektif}

SE atau sumbangan efektif merupakan ukuran sumbangan suatu variabel prediktor atau variabel independen terhadap variabel dependen. Penjumlahan dari sumbangan efektif untuk semua variabel independen adalah sama nilainya dengan Rsquare. Dari data dibawah ini maka diperoleh nilai SE yaitu:

Tabel 1. Output Analisis Regresi Linier Berganda

\begin{tabular}{cccc}
\hline Variabel & Koefisien Regresi & Koef Korelasi & Rsquare \\
\hline HPP & 0.545 & 0.816 & 0.823 \\
Beban Usaha & 0.480 & 0.787 &
\end{tabular}

$\mathrm{SE}=$ Koefisien Regresi $\times$ Koefisien Korelasi $\times 100 \%$

Sehingga;

SE HPP $=0,545 \times 0,816 \times 100 \%$ 


$$
=44,5 \%
$$

SE BU

$$
\begin{aligned}
& =0,480 \times 0,787 \times 100 \% \\
& =37,8 \%
\end{aligned}
$$

Dari data tersebut maka diketahui 82,3\% variabel HPP dan beban usaha yang mempengaruhi laba, HPP memberi sumbangan pengaruh sebesar 44,5\% dan beban usaha sebesar 37,8\%.

\subsubsection{Analisis Regresi Linier Berganda}

Analisis regresi linier berganda dilakukan untuk mengetahui besarnya pengaruh dari dua variabel bebas atau independen terhadap variabel dependen. Bentuk persamaan yang dihasilkan oleh analisis regresi linier yaitu:

$$
\mathrm{Y}=\mathrm{a}+\mathrm{b} 1 \mathrm{X} 1+\mathrm{b} 2 \mathrm{X} 2
$$

Tabel berikut menunjukkan hasil perhitungan analisis regresi linier menggunakan IBM SPSS 20.

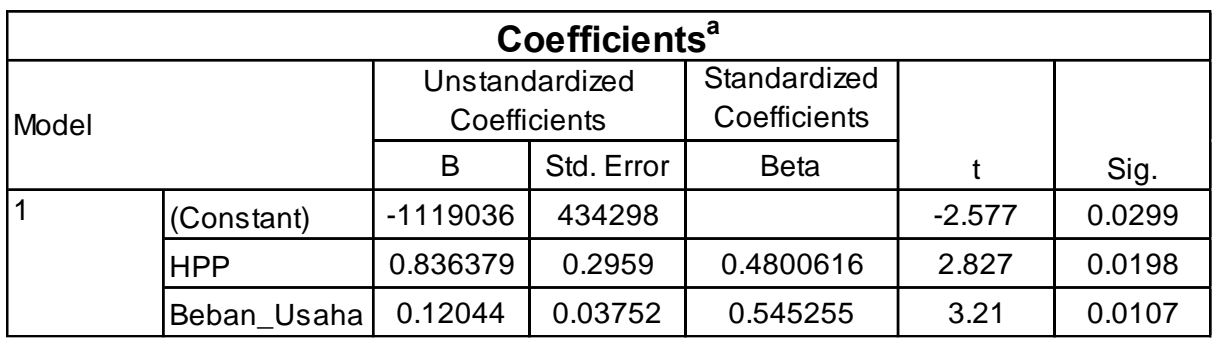

Gambar 6 Hasil SPPS Output Analisis Regresi Linier Berganda

Berdasarkan hasil output dari pengolahan data diatas diperoleh nilai a sebesar -1119036, nilai b1 sebesar 0,836379 dan nilai b2 sebesar 0,12044. Dengan demikian maka dapat dibentuk persamaan regresi sebagai berikut :

$$
Y=-1119036+0,836379 X 1+0,12044 X 2
$$

Dari persamaan regresi linier diatas nilai a sebesar -1.119.036 mempunyai arti jika beban usaha dan HPP bernilai nol maka tidak terjadi laba melainkan mengalami kerugian sebesar Rp.1.119.036 (dalam jutaan rupiah).

Koefisien regresi nilai b1 sebesar 0,836379 koefisien tersebut bernilai positif menunjukkan adanya arah yang sama antara beban usaha dengan laba bersih. Ini berarti jika setiap kenaikan beban usaha sebesar Rp.1 maka diprediksi akan meningkatkan laba sebesar Rp.0,836379.

Koefisien regresi nilai b2 sebesar 0,12044 koefisien tersebut bernilai positif menunjukkan arah yang sama berarti setiap kenaikan HPP sebesar Rp.1 maka diprediksi akan meningkatkan laba sebesar Rp.0,12044.

Dari model tersebut maka dapat dikatakan apabila HPP maupun beban usaha mengalami kenaikan maka laba juga akan mengalami kenaikan berdasarkan kasus perolehan laba di PT XYZ selama 
tahun 2006-2017. Hal tersebut menyebabkan model kurang tepat untuk digunakan karena bertolak belakang dengan teori yang ada yaitu semakin kecil HPP dan beban usaha maka nilai laba akan semakin besar, padahal HPP sendiri mempengaruhi laba sebesar 44,5\% dan beban usaha mempengaruhi laba sebesar 37,8\% menurut nilai sumbangan efektif dengan berdasarkan nilai Rsquare. Sehingga, dari hasil tersebut dapat disimpulkan variabel HPP dan beban usaha belum mampu menjadi leading indikator.

\subsection{Lagging Indikator}

Dalam lagging indikator, maka hal yang dapat dipantau atau dijadikan sebagai indikator adalah laba itu sendiri. Untuk indikator ini memiliki kelebihan mudah diukur namun sangat sulit untuk dilakukan perbaikan karena pengukuran dilakukan ketika hasil sudah keluar. Untuk pembuatan dashboard sendiri dilakukan penentuan kategori laba yang dibagi menjadi 3 yaitu bahaya, aman dan waspada. Hal tersebut akan memudahkan saat melakukan pengecekan bahwa laba yang ada sudah berada dalam kategori apa. Berikut penentuan kategori laba tersebut:

Tabel 2 Penentuan Kategori Laba

\begin{tabular}{cc}
\hline Laba-Laba & kategori \\
\hline rata-rata-Standar Deviasi & Bahaya \\
rata-rata-Standar Deviasi s/d Rata-rata+ \\
Standar deviasi & Waspada \\
>rata-rata+Standar Deviasi & \\
\end{tabular}

Tabel 3 Penentuan Kategori Laba

\begin{tabular}{cc}
\hline Laba-Laba & kategori \\
\hline $\operatorname{Rp} 586.788$ & Bahaya \\
$\operatorname{Rp} 586.788-\operatorname{Rp} 1.995 .230$ & Waspada \\
$>\operatorname{Rp} 1.995 .230$ & Aman \\
\hline
\end{tabular}

Untuk selanjutnya dalam dashboard tersebut juga dijelaskan mengenai latar belakang dibuatnya early warning system berbasis risiko tersebut yang kemudian juga dijelaskan dampak dari risiko yang ada. Kemudian terdapat pula informasi mengenai posisi laba baik menggunakan gafik maupun gauge yang terakhir juga disebutkan pula indikator yang mempengaruhi berdasarkan perhitungan analisis regresi linier berganda sebelumnya. 


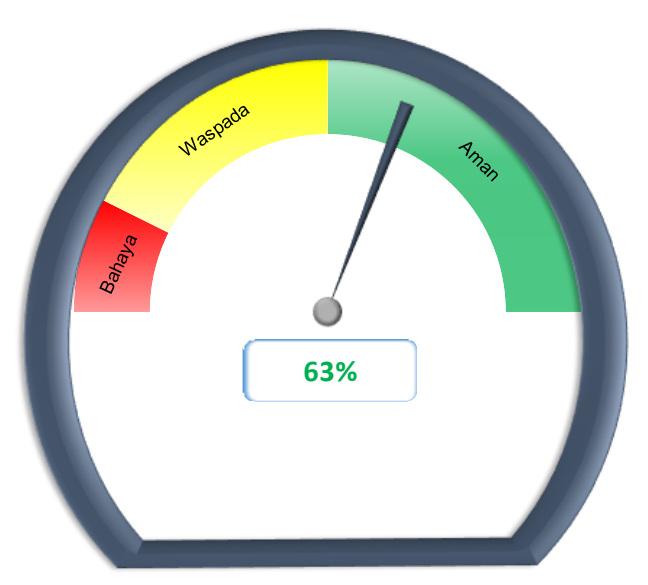

Gambar 7 Gauge Penentuan Kategori Laba

Untuk dashboard ini sendiri sebetulnya masih memiliki kekurangan, yaitu untuk kategori laba masih berdasarkan perhitungan laba dari tahun 2006-2017, sehingga apabila akan digunakan untuk tahun berikutnya perlu dilakukan perhitungan ulang dengan penambahan data yang ada. Selanjutnya untuk timeline dashboard sendiri diberlakukan dengan mengeluarkan hasil perhitungan risiko dari data 2 bulan sebelumnya dengan pertimbangan setidaknya dapat digunakan sebagai tindakan pencegahan apakah diperlukan perolehan laba yang lebih besar lagi agar target laba diakhir tahun dapat tercapai.

\section{Kesimpulan dan Saran}

Berdasarkan data keuangan PT XYZ tahun 2006-2017, untuk leading indikator diperoleh model laba $=-1119035,722+0,120$ HPP $+0,836$ beban usaha, untuk variabel dependen yaitu laba dan variabel independen yaitu HPP dan beban usaha. Hasil dari model tersebut menunjukkan bahwa laba berbanding lurus dengan HPP dan beban usaha. Hal tersebut menunjukan ketidaksesuaian dengan teori yaitu apabila HPP dan beban usaha mengalami penurunan maka laba akan semakin besar. Sehingga dapat disimpulkan HPP dan beban usaha belum mampu menjadi leading indikator.

Untuk lagging indikator digunakan tiga kategori laba yaitu bahaya, waspada dan aman. Dalam batas pengkategorian perlu dilakukan pembaruan data setiap tahunnya karena data yang ada untuk sekarang hanya berdasarkan data laba tahun 2006-2017. Early warning system dikeluarkan menggunakan data 2 bulan sebelumya agar dapat dilakukan pendeteksian.

Saran yang dapat diberikan yaitu perusahaan dapat menindaklanjuti penelitian ini karena dapat digunakan sebagai pemantauan laba sehingga risiko laba tidak tercapai tidak akan terjadi. Selanjutnya, penelitian ini belum menemukan nilai yang dapat digunakan sebagai model pasti sebuah early warning system sehingga diperlukan penelitian dengan mengembangkan indikatorindikator yang lebih luas agar early warning system dapat dimanfaatkan.

\section{REFERENSI}

[1] Muslich, Moh. (2007). Manajemen Risiko Operasional. Jakarta: PT. Bumi Aksara. 
[2] Susilo, L.J, \& Kaho, V. R. (2014). Manajemen Risiko Berbasis ISO 31000 untuk Industri Nonperbankan (Edisi Revisi). Indonesia: PPM Manajemen.

[3] Rahardjo, B. (2007). Keuangan dan Akuntansi. Yogyakarta: Graha Ilmu.

[4] Jusuf, J. (2006). "Pengaruh Biaya Operasional Terhadap Rentabilitas pada Sektor Perbankan". Skripsi. Fakultas Ekonomi. Universitas Komputer Indonesia. Bandung .

[5] Efilia, M. (2014). Pengaruh Pendapatan Usaha dan Beban Operasional Terhadap Laba Bersih Pada Perusahaan Kimia dan Keramik, Porselin \& Kaca yang Terdaftar di Bursa Efek Indonesia Periode 2008-2012. E-Journal: Jurnal UMRAH. Diakses dari http://jurnal.umrah.ac.id/wp-content/uploads//JURNAL-MEIZA-EFILIA.pdf

[6] Novita, Rian. (2018). Analisis Faktor-Faktor Yang Mempengaruhi Berfluktuasinya Net Profit Margin Ratio Pada CV. Tulimario Tangkit Baru Kabupaten Muaro Jambi. Jurnal Manajemen Jambi. 1(1): 35-41.

[7] Genocideprevention, Freswater. (2003). Early Warning System. [Online]. http://www.genocideprevention.org/earlywarning.html

[8] International Standard for Organization. (2009). Risk Management - Principle Guidelines. Diakses dari International Standard for Organization website: https://www.iso.org/standard/43170.html

[9] Ghozali, I. (2013). Aplikasi Analisis Multivariate dengan Program IBM SPSS 21. Edisi 7. Semarang: Universitas Diponegoro.

[10] Basuki, A. T. (2017). Bahan Ajar Ekonometri. Yogyakarta: Universitas Muhammadiyah Yogyakarta. 